\title{
The Correlation between Toll Road Development and the Improvement of Local Economy (Case Study: The Soroja Toll Road)
}

\author{
Lisna Rahayu ${ }^{*}$, and Desiree Marlyn Kipuw ${ }^{1}$ \\ ${ }^{1}$ School of Architecture, Planning and Policy Development, Institut Teknologi Bandung, Jl. Ganesha 10, Bandung, \\ 40132, Indonesia \\ *Email: lisnarahayu@sappk.itb.ac.id
}

\begin{abstract}
Most studies assume that road development will improve the economy in the region, as reflected by an increase in Gross Domestic Product (GDP). However, GDP is macro in nature and tends to be biased if we ask who benefits from its increase. To identify whether road development has a positive correlation with the improvement of local economy, hence this study was conducted in a micro context by taking the development of the Soroja Toll Road in Indonesia as a case study. With a length of $10.57 \mathrm{~km}$, connecting Bandung Regency and Bandung City, the newly constructed Soroja Toll Road has a strategic function in supporting activities in the Bandung Metropolitan Area (BMA) and is predicted giving implication on increasing Small and Medium Enterprises (SMEs) profit surrounding its corridor. However, a toll road cannot entirely be seen as a public goods, because not all people have access to this type of infrastructure. Only the users of four-wheeled vehicles and those who can afford to pay the toll charge can access the toll road. This study was aimed at identifying the correlation between the developments of the Soroja Toll Road with the improvement of local economy (SMEs) in its surrounding areas. Based on the analysis result, this study indicates that the presence of the Soroja Toll Road had a bigger positive correlation with the increased profit of medium-sized industries than small-sized industries due to their ability to capture a broader market.
\end{abstract}

\section{Keywords}

Toll road development; Correlation; Local economy; SMEs

\section{Introduction}

Several pieces of research have empirically proven that there is a strong correlation between new road construction and regional economic development [1-4]. The construction of new roads always leads to an increase in the movement of goods and passengers and to growth of economic activity $[5,6]$. One of the newly completed road development projects in the Bandung Metropolitan Area is the Soreang-Pasir Koja Toll Road (The Soroja Toll Road). This $10.57 \mathrm{~km}$ long toll road connects Bandung Regency with Bandung City and has a strategic function in supporting economic activity in the Bandung Metropolitan Area (BMA). Moreover, in the National Plan 2008-2028, the BMA has been established as a strategic area whose spatial planning is prioritized due to its large influence on the economy of West Java and Indonesia in general. Thus, the presence of the Soroja Toll Road is expected to increase the movement of goods and economic activity and is considered strategic not only from the perspective of Bandung Regency but also from the perspective of West Java Province and the national government.
One of the indicators commonly used to measure the development of a region is gross domestic product (GDP). In relation to road construction, most studies assume that the construction of new road networks will influence the regional economy, as reflected in an increase of GDP $[7,8]$. Even though this is theoretically correct, GDP is macro in nature and tends to be biased if we look at who benefits from its increase. If this indicator is used as a measure for improving economic wellbeing, it is unable to correctly reflect its influence on the welfare of local communities. Based on this argument, to find out whether the construction of the Soroja Toll Road has a positive correlation with the local economic improvement it is necessary to analyze it in a micro context.

The sector that can best represent the economic condition of a local community is the SME sector (small and medium-sized enterprises). Efforts to encourage the development of SMEs are mandated in Indonesian Law No. 20/2008 concerning Micro, Small and Medium Enterprises. In the current conditions, the sub-districts along the Soroja Toll Road's corridor have developed into centers of accumulation of SMEs, mainly from the 
textile, handicrafts and agro industrial sectors. The Soroja Toll Road is predicted to have a positive effect on the development of SMEs in this region, especially through the reduction of transportation costs in distributing products. Besides that, the Soroja Toll Road also has the potential to broaden the market area and even attract investment to Bandung Regency, which could drive the regional economy. However, a toll road cannot entirely be seen as a public goods since not all people have equal access. Only users of four-wheeled vehicles and those who can afford to pay the toll road fee can access a toll road. Based on this argument, it is necessary to identify whether the construction of the Soroja Toll Road has a positive correlation with the improvement of local economy (SMEs profit) in Bandung Regency.

This paper is structured as follows. First, we provide a theoretical review based on earlier studies that indicate the correlation between street or highway development and local economic growth, and the classifications of SMEs that are commonly used. Then we explain the details of the study location and describe the methodologies that we used to collect and analyze the data. In the next section, we explain the result of our research in detail. In the last section, the conclusion is provided and recommendations are given to optimize the positive impact of toll road development in strengthening the local economy.

\section{Theoretical Review: Highway Construction and its Influence on Local Economic Development, Who gets the Benefit?}

The development of transportation infrastructure has a tight correlation with the growth of land use and economic activities [5,6,9]. Bertolini [10] defines this correlation as a transport land-use feedback cycle due to the fact that both will influence each other. In very complex situations transport and land-use planning can be integrated to cultivate the links of these two aspects with other aspects such as economic, social, and cultural processes. In the context of Indonesia, the evidence of this correlation has been provided by Firman [11], who indicates that the opening of the new Jakarta-Bandung Toll Road encouraged several economic activities to grow and triggered new socio-economic development in some areas along the toll road. Other evidence has been provided by Pradono and Handini [12]. By using an input-output analysis, their study showed that the investment value for the Bandung Intra Urban Toll Road (BIUTR) stimulated the city's economy through the impact of output, income, and employment. Prapti et al. [13] has provide some statistical evidence that there has been a positive and significant influence from infrastructure development towards economic growth and social aspects in Semarang City. In addition, Anas et al. [14] indicate that road infrastructure investment in Indonesia tends to affect the production sector and regional economies of Indonesia in general.

The existence of this correlation between transportation infrastructures, land use, and beyond implies that investment in new infrastructure will have multiple impacts on many aspects. Thus, before it is constructed, many considerations are usually taken into account to make sure that the development will have a positive impact instead of negative externalities. Obviously, the rationale behind this is that toll road construction costs big money; infrastructure development is usually very expensive. Hundreds if not thousands of billions of dollars are tied up in the provision of new infrastructure [15]. As a consequence, in an effort to make infrastructure development more on target with more positive impact and less negative externalities, many researchers have argued that providing more sustainable infrastructure is a must. Several studies on sustainable transportation infrastructure development have been conducted in various settings. Some of them by integrating design, construction, and maintenance [16], by examining institutional and regulatory aspects [17], or by shifting the paradigm from conventional to more sustainable mobility [18].

In spite of its wide correlation, this study put more emphasis on transportation infrastructure development, especially road construction and its correlation to the growth of economic activities. From an economic perspective, the existence of a transportation system is always associated with facilitation of the exchange of goods, expansion of marketing area, offsetting the scarcity of production in other regions, and increased price stability. McCann (2013) [19] in Adisasmita (2010) [20] argue that the ongoing transportation activities are partly due to the heterogeneity of the earth's surface, which has implications for the occurrence of specialization of production between regions. Transportation is necessary to support the exchange of produced goods since there is no one region can fulfill all of its own needs without the support of production in other regions. The growing trend of specialization in production has resulted in the need for transportation support to transport raw materials from the source to the production site and to distribute the production result to the market.

If we simplify these economic activities, opening a new road means improvement of transportation 
accessibility. High accessibility of transportation facilitates the distribution of goods and stimulates market openness [21-23] and reduces production costs $[24,25]$, which will eventually increase the productivity of firms in a specific location, which in turn attracts similar firms, forming an agglomeration economy [26].

Many studies associate infrastructure development with regional economic development in a macro context through the increase of GDP, for example, previous studies conducted by Sun et al. in 2018 [7]; Chung in 2002 [8]; Pradono and Pradhitasari in 2011 [12]; and Odeck in 2017 [27]. However, in the context of toll road construction, the question that emerges next is who benefits. Only those who have access to toll roads, i.e. those who can afford to pay the toll fee and use a fourwheeled vehicle. In fact, toll road fees may increase transportation costs, and not all producers can afford this additional cost. Holl [28] highlights the shift from macro to micro analysis in identifying the effect of infrastructure investment.

\subsection{Production cost}

Production costs can be defined as all costs incurred by a company to obtain production factors and raw materials to be used in the production process [29]. In the context of transportation, transportation costs that must be borne by the producer in producing an item are a component of the production costs, which determine the selling price of a product. In manufacturing activities, the task of transportation is to convey raw materials from the source to the factory and to move the goods produced from the factory to the market place and end-consumer [30]. Thus, it can be inferred that transportation costs may comprise assembly costs and distribution costs, which can be illustrated in Figure 1 as follows.

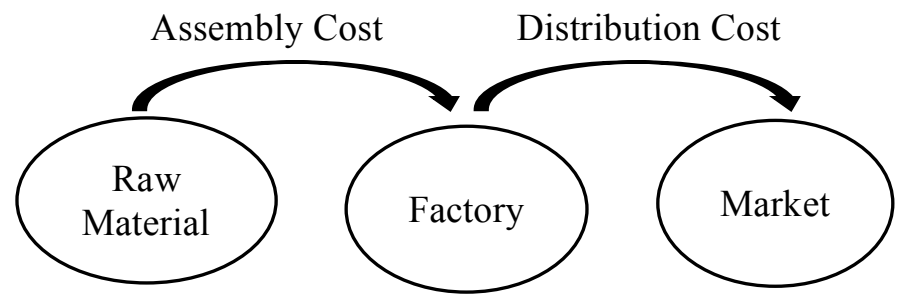

Figure 1 Transportation costs in the production process.

The above scheme classifies transportation costs based on the time of the production stage, comprising pre- and post-production. In the pre-production stage, to bring raw materials from the raw material source to the production site (factory), the producer spends transportation costs in the form of assembly costs. In the post-production stage, the producer spends transportation costs to distribute the product to the market to be subsequently sold to consumers. The transportation cost component is one of the factors that the producer considers in the production process. Furthermore, transportation costs can influence the producer's decisions in determining the location of production, either closer to the raw material source or closer to the market.

\subsection{Revenue and profit in relation to reduce transportation cost}

According to Sukirno [29], in economic theory, a company is seen as a collection of business entities that have the same goal, i.e., to achieve optimum profit through efficient use of production factors. Profit can be formulated as the difference between revenue and production costs. A producer is deemed to be profitable if he gets income from sales that is greater than the cost of production and vice versa. The results of sales (revenue, denoted by R) itself can be formulated as a multiplication of quantity of sold goods $(\mathrm{Q})$ and the selling price of goods $(\mathrm{P})$ with the following equation [31]:

$$
R=Q \times P
$$

The profit of a company in producing a product can be formulated with the following equation [31]:

$$
Y=R-C
$$

Where:

$$
\begin{aligned}
& \text { Y : Profit } \\
& \text { R : Revenue } \\
& \text { C : Total Cost }
\end{aligned}
$$

The construction of the Soroja Toll Road potentially reduces transportation costs, assuming that producers will no longer bear the cost of traffic congestion in the form of wasteful fuel expenditure and will experience a reduction of the time spent to distribute products. On the other hand, better transportation access is also assumed to be able to expand the marketing area of the produced goods. Thus, in the context of this study, the impact of the construction of the Soroja Toll Road on improving the welfare of SMEs can be approached by substituting first equation to second equation as the following mathematical equation:

$$
Y=Q \times P-T+F
$$


Or it can be formulated as a function of quantity, price and transportation costs as follows:

$$
Y=f(Q, P, T, F)
$$

Where:

Y : Profit ratio between after and before the construction of the Soroja Toll Road.

Q : Production Quantity ratio between after and before the construction of the Soroja Toll Road.

$\mathrm{P}$ : Product price ratio between after and before the construction of the Soroja Toll Road.

$\mathrm{T}$ : Transportation cost ratio between after and before the construction of the Soroja Toll Road.

$\mathrm{F}$ : other factors that have not been identified

This function or formula provides an argument regarding factors that affect the profit of SMEs by taking into account the development of Soroja Toll Road. These four variables are then will be modelled to identify how significantly each independent variable (Production Quantity Ratio, Product Price Ratio and Transportation Cost Ratio) correlates with the increase of SMEs' profit to further identify what should be intervened the most to maximize the profit of SMEs.

\subsection{Small and medium enterprises (SMEs)}

SMEs are among the main actors in the economy. The role of SMEs in the economy is reflected in employment, empowerment of local communities, and their contribution to GDP. Apart from that, SMEs are also considered to be creators of innovations with unique characteristics in the form of new products for local and foreign markets. In developing countries, SMEs contribute around $60 \%$ to employment and contribute around $40 \%$ to GDP [32]. In Indonesia, in 2012 it has been identified that there were 56,534,592 units of SMEs with a proportion of $99.99 \%$ of the total number of industries in Indonesia, and only $0.01 \%$ were categorized as large industries [33]. Compared to other types of industries, SMEs are considered to be more stable because they do not depend on large capital or payments in foreign currencies so that they are not affected by fluctuations in currency exchange rates. In the Indonesian context, this was proven by the survival of the SME sector despite the shock of the economic crises in 1998.

The definition of MSMEs (Micro, Small, and Medium Enterprises) varies greatly depending on the context of the country in which the SMEs are located, however, in general the classification of SMEs used in this research is based on 3 main variables: 1) size of workforce, 2) income, and 3 ) total assets possessed.

The usage of workforce as an indicator to categorize MSMEs is broadly used, for example by the World Bank and Eurostat's Structural Business Statistics (SBS) $[34,35]$. In the Indonesian context, the Central Bureau of Statistics has also released the classification. In this research, the last classification is applied due to the argument that this classification tends to be more appropriate to be applied in the Indonesian context. Meanwhile for the criteria of the amount of net income and assets of MSMEs, the classification of MSMEs is regulated in a number of regulations, including Law No. 20/2008 concerning Micro, Small and Medium Enterprises and in Bank Indonesia Regulation No. 7/39/PBI/2005 concerning Provision of Technical Assistance in the Development of Micro, Small and Medium Enterprises. In this study, the definition and classification of MSMEs from Law No. 20/2008 was used, due to the argument that this regulation is a statute that become an umbrella for all policies in Indonesia. Apart from that, this law was issued more recently than the $\mathrm{BI}$ regulation, so it is expected that the determination of the characteristics of the amount of income and assets of MSMEs considers the dynamics of Indonesia's recent economic growth. As the summary, categories of MSMEs used in this research are provided in Table 1.

\section{Study Area}

This research was conducted at three sub-area developments in Bandung Regency that are within the capture radius of Soroja Toll Road, comprising Subarea development of Soreang-Kutawaringin-Katapang, Sub-area development of Margahayu-Margaasih, and Sub- area development of Banjaran (See Figure 2).

Table 1 Categories of MSMEs Used in This Research [36,37]

\begin{tabular}{lccc}
\hline $\begin{array}{c}\text { Type of } \\
\text { Business }\end{array}$ & Workforce & $\begin{array}{c}\text { Annual } \\
\text { Sales }\end{array}$ & $\begin{array}{c}\text { Assets } \\
\text { (Besides } \\
\text { land and } \\
\text { buildings) }\end{array}$ \\
\hline Micro & $\leq$ Five people & $\leq$ IDR 300 & $\leq$ IDR 50 \\
& million & million \\
Small & 5-19 people & IDR 300 & IDR 50 \\
& & million - IDR & million - IDR \\
& & 2.5 billion & 500 million \\
Medium & 20-99 people & IDR 2.5 & IDR 500 \\
& & billion - IDR & million - IDR \\
& & 50 billion & 10 million \\
\hline
\end{tabular}




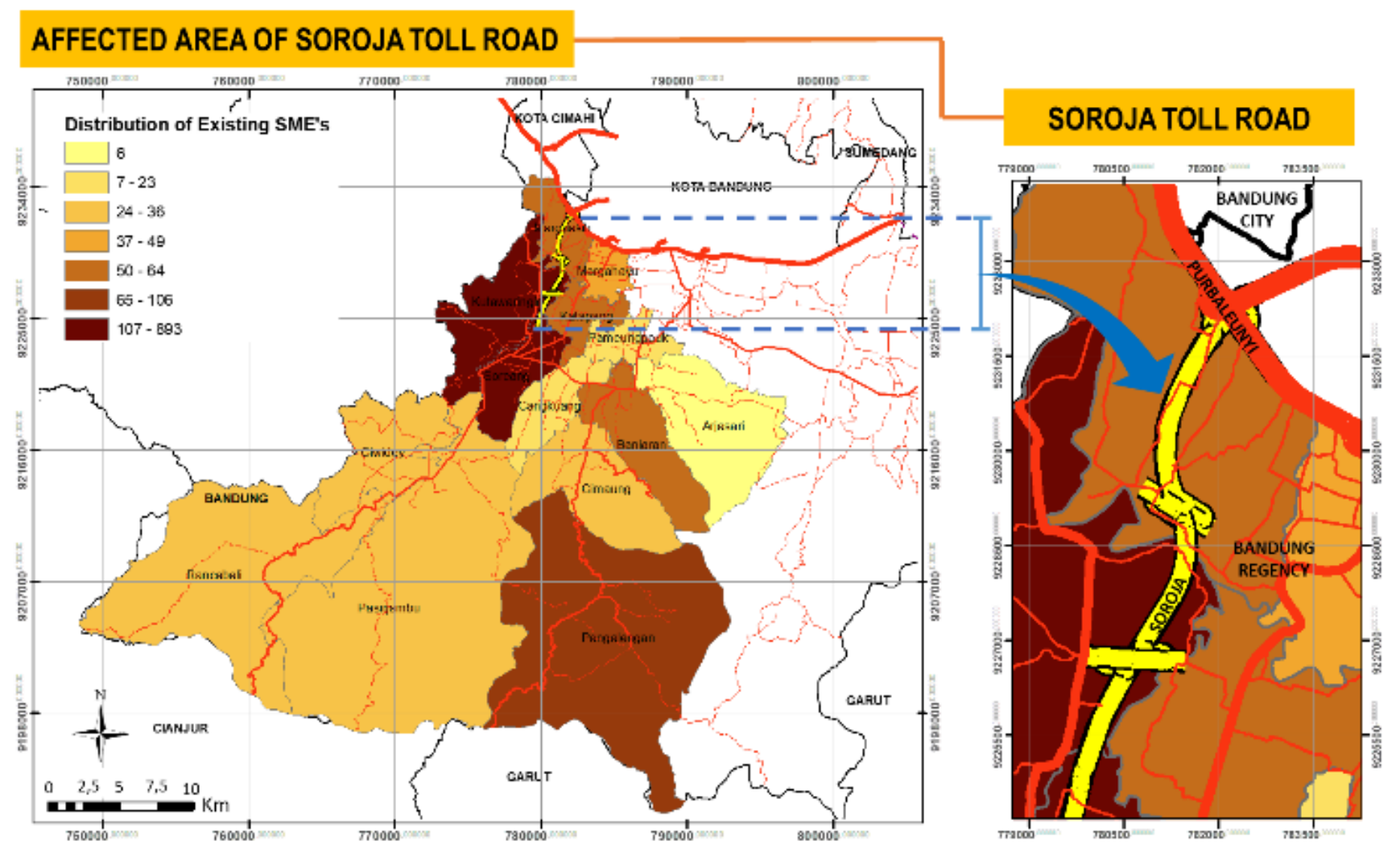

Figure 2 Area affected by the Soroja Toll Road

\section{Research Methodology}

\subsection{Methodology to collect data}

Data collection to support this research was conducted with primary survey by spreading questionnaires. The population in this research is all small and medium enterprises in Bandung Regency surround the Soroja Toll Road. Meanwhile the number of sample is determined by using Slovin formula. With level of confidence $95 \%$, sampling error $5 \%$ and assuming that population variance is $50 \%(\mathrm{p}=0.5)$, the total questionnaire spread were 321 small and medium enterprises, 289 of it were Small Enterprises, and 32 others were Medium Enterprises. This proportion follows the structure of SMEs population in the study area, in which $97 \%$ of SMEs are dominated by small enterprises.

The determination of sample was conducted by using Stratified Random Sampling. This sampling technique allows samples to be evenly distributed and represent the entire population. The questionnaire is divided into three section. The first section is about the identity of the respondent, such as age, gender, education level, and type of industry they owned. The second section, is about the characteristic of the small and medium industries. In this section, the respondents were asked about several indicators that are compared between before and after the construction of Soroja Toll Road. These indicators comprises employee size, production per month, product price, transportation cost per month both to transport raw materials from the source of the raw material to the factory and to distribute the produced goods from factory to the market, location of their market, revenue and profit of small and medium enterprises. The third section of the questionnaire is about the characteristic of transportation of small and medium enterprises. In this section, the respondents were asked whether the small and medium enterprises use private or public transportation and whether there is a change of mode of transportation between before and after the development of Soroja Toll Road as well as their reason to change or to keep using the similar mode of transportation to support their production.

\subsection{Methodology to analyze data}

To measure the productivity of SMEs in relation to the presence of the Soroja Toll Road, descriptive and comparative analysis were applied. Meanwhile, to identify the correlation between the productivity of SMEs expressed in profit and its independent variables (production, product prices, and transportation costs), a linear regression analysis was carried out. 


\section{Analysis Result: The Correlation between the development of the Soroja Toll Road and SMEs Productivity.}

One of the indicators used as a parameter to measure the productivity of SMEs in relation to the presence of the Soroja Toll Road was profit received by the SMEs. Based on the results of the literature study described in Section 2, profit can be determined by using at least three main variables, i.e., production quantity, the price of goods, and transportation costs incurred by the producer. These three variables were compared between before and after the construction of the Soroja Toll Road. Before further discussing the correlation between the profit and these three dependent variables, firstly, the level of correlation between the development of the Soroja Toll Road and each variables will be explained.

1. The Correlation between the Soroja Toll Road Development and the Profit of SMEs

Based on the survey data, there was a significance difference between perceptions of small-sized industry actors and of medium-sized industry actors regarding the correlation of Soroja Toll Road development on SME profits in the areas around the Soroja Toll Road. This study classifies the level of correlation into the following three classes:

- Negatively correlated, with a profit ratio between after and before construction of the Soroja Toll $\operatorname{Road}<1$;

- Not correlated, with a profit ratio between after and before construction of the Soroja Toll Road $=1$; and

- Positively correlated, with a profit ratio between after and before construction of the Soroja Toll Road $>1$;

The analysis result (See Figure 3) indicates that for small industries, the development of the Soroja Toll Road tend to have no any correlation with their profit. Around $57.22 \%$ of small-sized industries stated that their profit obtained between before and after the construction of the Soroja Toll Road are the same. Only $36.36 \%$ of them stated that there was a positive correlation of the presence of the Soroja Toll Road in increasing their profit, proved by the profit ratio between after and before the construction of the Soroja Toll Road that was greater than 1 . The rest, $6.42 \%$, stated that the presence of the Soroja Toll Road has negative correlation with their profit, proven by their decreased profit after the development of the toll road. This result implies that during one year after completion of the toll road, the majority of small-sized industry businesses did not get the positive benefit of the Soroja Toll Road Development.

In contrast to the trend among small-sized industries, $77.27 \%$ of medium-sized industries stated that there was a positive correlation between the presence of the Soroja Toll Road and their profit. Majority of Mediumsized industries had an increase in profits after the construction of the Soroja Toll Road. Only around $19.70 \%$ stated that there was no correlation, and about $3.03 \%$ stated that it had a negative correlation and got lower profit after the presence of the Soroja Toll Road.

These comparative profit data indicate that the construction of the Soroja Toll Road did not give equal benefits to SMEs. Gaining profit, in this case, was a matter of in how far the industries were capable of capturing the opportunities to expand their marketing area. Based on these data, it can be inferred that medium-sized industries tend to be more able to capture these opportunities provided by the presence of the toll road than small-sized industries.
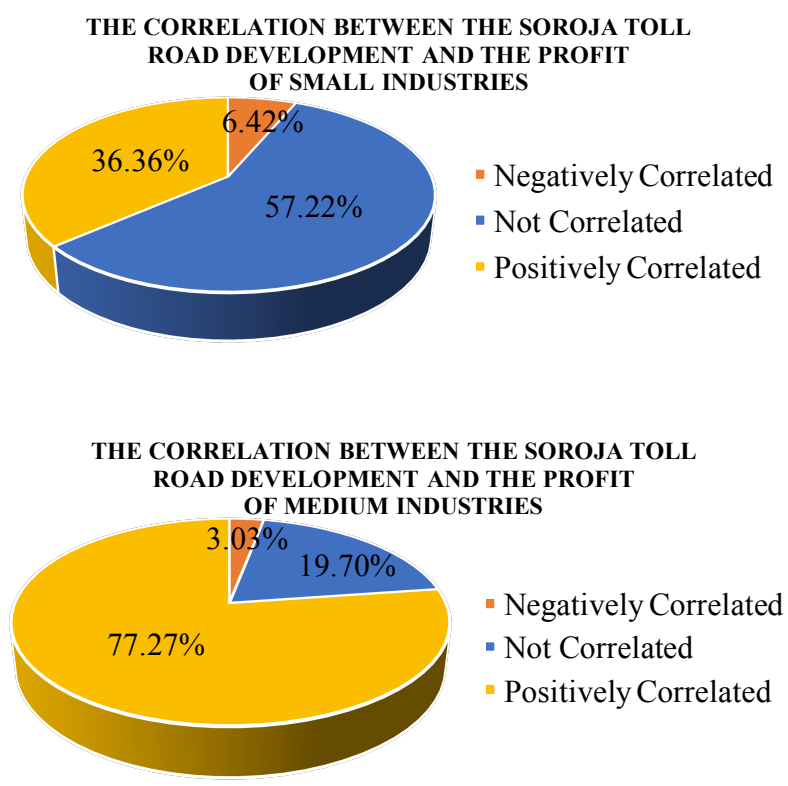

Figure 3 The correlation between the Soroja Toll Road development and the profit of SMEs

2. The Correlation between the Soroja Toll Road Development and the Goods Production of SMEs

The level of correlation between the development of the Soroja Toll Road and the production of the goods of SMEs was classified into the following three classes:

- Negatively correlated, with a ratio of the quantity of SMEs production between after and before construction of the Soroja Toll $\operatorname{Road}<1$; 
- Not correlated, with a ratio of the quantity of SMEs production between after and before construction of the Soroja Toll Road $=1$; and

- Positively correlated, with a ratio of the quantity of SMEs production between after and before construction of the Soroja Toll Road $>1$;

Based on the analysis result (See Figure 4), the presence of the Soroja Toll Road tended to be more correlated with the increased production of medium-sized industries than to small-sized industries. The results of the identification to small-sized industries showed that $60.96 \%$ of them did not experience an increase in the amount of production after the construction of the Soroja Toll Road. Only around $33.16 \%$ had positive correlation with an increase in the amount of production after the construction of the Soroja Toll Road, and around $5.88 \%$ tended to have a negative correlation which were proven by a decrease in the amount of production after the construction of the Soroja Toll Road.
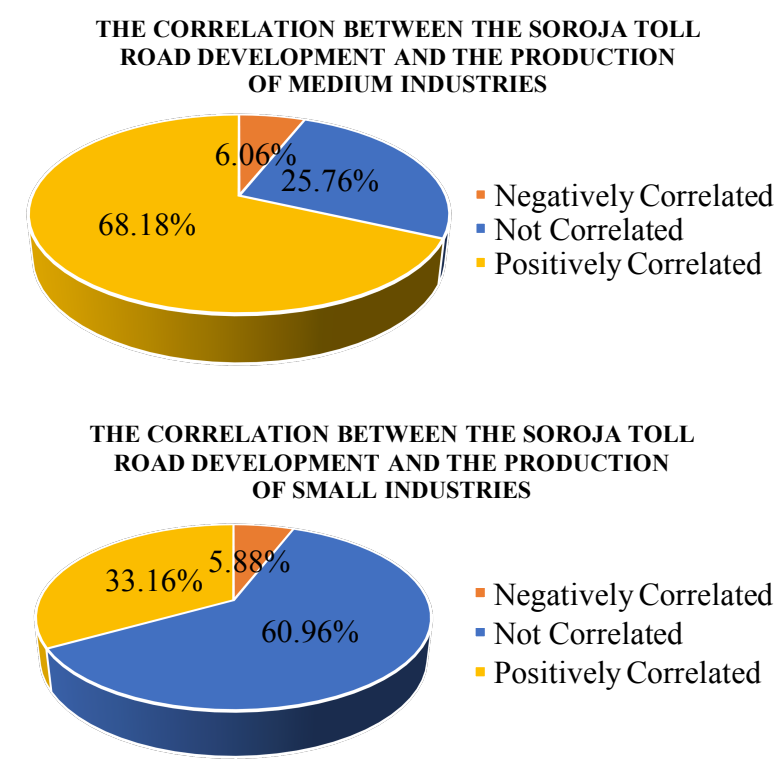

Figure 4 The correlation between The Soroja Toll Road Development and the production quantity of SMEs.

The opposite occurred among the medium-sized industries. Most of the medium-sized industry players, which amounted to $68.18 \%$, tended to have positive benefits from the presence of the Soroja Toll Road with an increase in the production quantity. Only about $25.76 \%$ of medium-sized industry actors stated that there were not any correlation between the presence of the Soroja Toll Road and the production of their goods, and only $6.06 \%$ of the medium-sized industries had a negative correlation and experienced a decrease in their production quantity.

By comparing the correlation between the construction of the Soroja Toll Road and the production quantity of small and medium-sized industries, it can be concluded that the medium-sized industries tend to be more competitive and better able to capture market opportunities than small-sized industries. Thus, in the future, in the context of optimizing the impact of the Soroja Toll Road on the productivity of small-sized industries, facilitation of small-sized industries in efforts to increase their production and access a wider market area is required.

3. The Correlation between the Soroja Toll Road Development and the Product Price of SMEs

Similar to the profit and goods production aspects, the level of correlation between the construction of the Soroja Toll Road and the product price of the SMEs was classified into the following three classes:

- Negatively correlated, with a product price ratio between after and before the construction of the Soroja Toll $\operatorname{Road}<1$;

- Not correlated, with a product price ratio between after and before the construction of the Soroja Toll Road $=1$; and

- Positively correlated, with a product price ratio between after and before the construction of the Soroja Toll Road $>1$;

Analysis result indicates that there appears to be an almost equal distribution between SMEs that benefited from an increase in the product price and SMEs that did not benefit from it, both for smallsized industries and medium-sized industries. Among small-sized industries, $60.96 \%$ tended to have a positive correlation between the presence of the Soroja Toll Road and their product price, evidenced by a price ratio after and before the existence of the Soroja Toll Road that greater than one. $38.50 \%$ tended to have no correlation. In other words, with the presence or absence of the Soroja Toll Road, the prices of the products tended to be the same. Only about $0.53 \%$ of small-sized industries had a negative correlation, proven by the decrease of their product prices. Meanwhile, among the medium-sized industries, the proportion between those that had a positive correlation and those that had not any correlation been nearly equal. The detail analysis result is provided in Figure 5. 


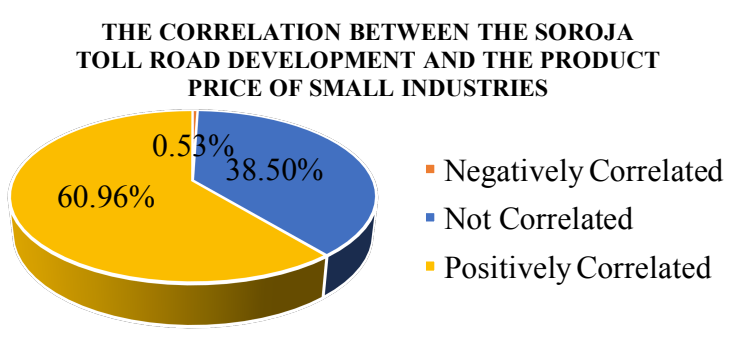

THE CORRELATION BETWEEN THE SOROJA TOLL ROAD DEVELOPMENT AND THE PRODUCT PRICE OF MEDIUM INDUSTRIES

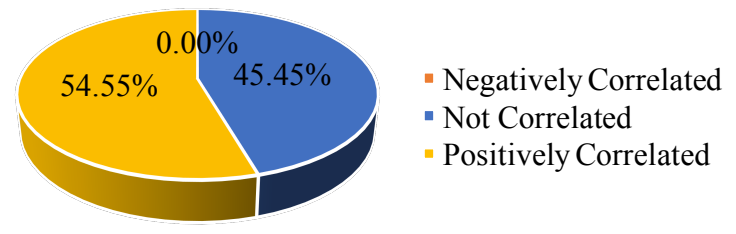

Figure 5 The correlation between The Soroja Toll Road Development and the product price of SMEs.

4. The Correlation between the Soroja Toll Road Development and the Transportation Costs of SMEs

The level of correlation of the presence of the Soroja Toll Road on the transportation costs of SMEs for bringing raw materials and distributing produced goods was classified into the following three classes:

- Negatively correlated, with a transportation costs ratio between after and before the construction of the Soroja Toll Road $<1$;

- Not correlated, with a transportation costs ratio between after and before the construction of the Soroja Toll Road = 1; and

- Positively correlated, with a transportation costs ratio between after and before the construction of the Soroja Toll Road $>1$;

In terms of transportation costs, although the initial hypothesis predicted that the presence of the Soroja Toll Road would decrease transportation costs, the survey results show that most small and medium-sized industries tended not to be affected by the presence of the Soroja Toll Road. More than $80 \%$ of both small and medium-sized industries did not experience an increase or decrease in transportation costs. This was due to the diverse transportation patterns of SMEs, especially in the clothing industry, which does not have direct transportation costs. In most cases, the SMEs receive raw materials directly from buyers (consumers) so that they do not spend money to bring in raw materials. Likewise, concerning the distribution of SME finished products, it is often the case that consumers, generally large consumers, take the goods directly from the SMEs, and as a consequence, the SMEs do not have transportation costs when distributing their products to the market. Detailed information about the correlation between the presence of the Soroja Toll Road and their transportation costs is presented in Figure 6.
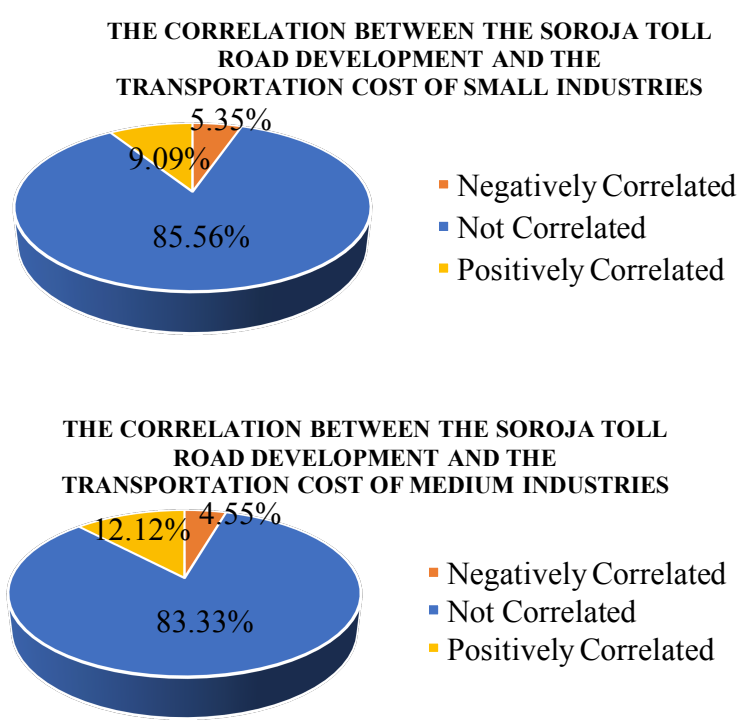

Figure 6 The correlation between the Soroja Toll Road Development and the transportation costs of SMEs.

To identify the correlation between the productivity of SMEs expressed in profit and the independent variables i.e. production, product prices, and transportation costs, a linear regression analysis was carried out. Before further modeling the correlation between the dependent variables and the independent variables, Pearson correlation tests were carried out to identify the correlations between the variables that would be used in the regression. This was done to avoid the use of independent variables that were auto correlated. The Pearson correlation test results on the variables used in the regression equation are presented in Table 2. 
Table 2 Pearson Correlation Test Result

\begin{tabular}{lcccc}
\hline & $\begin{array}{c}\text { Profit } \\
\text { Ratio }\end{array}$ & $\begin{array}{c}\text { Production Quantity } \\
\text { Ratio }\end{array}$ & $\begin{array}{c}\text { Product } \\
\text { Price Ratio }\end{array}$ & $\begin{array}{c}\text { Transportation Cost } \\
\text { Ratio }\end{array}$ \\
\hline Profit Ratio & 1,000 &, 815 &, 051 &, 213 \\
$\begin{array}{l}\text { Production Quantity } \\
\text { Ratio }\end{array}$ &, 815 & 1,000 &, 047 &, 171 \\
$\begin{array}{l}\text { Product Price Ratio } \\
\begin{array}{l}\text { Transportation Cost } \\
\text { Ratio }\end{array}\end{array}$ &, 051 &, 047 & 1,000 &, 067 \\
\hline
\end{tabular}

Table 3 Linear Regression Result

\begin{tabular}{|c|c|c|c|c|c|c|c|c|c|c|c|}
\hline \multirow{2}{*}{\multicolumn{2}{|c|}{ Model }} & \multicolumn{2}{|c|}{$\begin{array}{l}\text { Unstandardized } \\
\text { Coefficients }\end{array}$} & \multirow{2}{*}{$\begin{array}{c}\begin{array}{c}\text { Standardized } \\
\text { Coefficients }\end{array} \\
\text { Beta }\end{array}$} & \multirow{2}{*}{$\mathbf{t}$} & \multirow{2}{*}{ Sig. } & \multicolumn{3}{|c|}{ Correlations } & \multicolumn{2}{|c|}{$\begin{array}{c}\text { Collinearity } \\
\text { Statistics }\end{array}$} \\
\hline & & B & $\begin{array}{l}\text { Std. } \\
\text { Error }\end{array}$ & & & & $\begin{array}{l}\text { Zero- } \\
\text { order }\end{array}$ & Partial & Part & Tolerance & VIF \\
\hline 1 & (Constant) &,- 068 & 087 & &,- 774 & ,440 & & & & & \\
\hline & Production Quantity Ratio & ,952 &, 044 & ,802 & 21,699 &, 000 &, 815 & ,809 & ,790 & ,970 & 1,031 \\
\hline & Product Price Ratio & ,006 & ,026 &, 008 & ,218 &, 827 &, 051 &, 014 &, 008 & ,994 & 1,006 \\
\hline & Transportation Cost Ratio & ,159 & ,077 & ,076 & 2,052 &, 041 & ,213 & 129 &, 075 & ,967 & 1,034 \\
\hline
\end{tabular}

a. Dependent Variable: Profit Ratio

Based on the results of the correlation test in Table 2, it can be observed that the correlation between the independent variables tended to be smaller than 0.5 . This indicates that the independent variables did not have autocorrelation so that all independent variables could be used in the process of determining the regression model. The linear regression results of the correlation on the productivity of SMEs regarding the construction of the Soroja Toll Road are presented in Table 3.

Based on the above regression result, the correlation of the effect of the independent variables on the dependent variable as a result of the presence of the Soroja Toll Road is expressed in the following equation. The coefficient of the regression equation is obtained from column B in the regression.

$$
Y=0.952 x_{1}+0.006 x_{2}+0.159 x_{3}-0.068
$$

Where:

Y : Profit ratio between after and before the construction of the Soroja Toll Road

$x_{1}$ : Production quantity ratio between after and before the construction of the Soroja Toll Road

$x_{2} \quad$ : Product price ratio between after and before the construction of the Soroja Toll Road

$x_{3}$ : Transportation cost ratio between after and before the construction of the Soroja Toll Road

Based on the above equation, it appears that the increase in SME profit was largely determined by the variable of production quantity ratio $\left(x_{1}\right)$. An increase in the number of SME products ratio by one unit is predicted to be able to increase profits ratio by 0.952 times. Compared to the other two independent variables (product price and transportation costs), the production quantity variable tended to be the most dominant and had the highest correlation with the increase in profit.

The second variable that had a positive impact on increasing SME profit was the variable of transportation costs $\left(x_{3}\right)$. Although the initial hypothesis stated that transportation costs are negatively correlated with profit, the regression results showed a positive correlation between the transportation costs variable and the profit variable with a coefficient value for the transportation costs variable of 0.159 . This means that an increase in one unit of transportation costs ratio is predicted to increase the profit ratio of SMEs by 0.159 units. This positive correlation occurs as a result of the fact that the transportation costs used are not transportation costs per product unit but the transportation costs of all SMEs activities. Thus, the higher transportation costs can be assumed to be the result of an increase/expansion in marketing areas, and therefore it shows a positive correlation. The higher transportation costs indicate that, the broader the marketing area and the higher the productivity of the SMEs.

Meanwhile, for the product price variable $\left(x_{2}\right)$, the linear regression results indicated a very low correlation between increasing product prices and increasing SME profits. This is reflected in the value of the variable coefficient of the product price ratio, which was very low, with a coefficient of 0.006 . This indicates that an increase in the product price ratio of one unit is 
predicted to only increase SME profit by 0.006 units. This is much lower than the average increase of the variables product quantity $\left(x_{1}\right)$ and transportation costs $\left(x_{3}\right)$. In addition, if we look further by testing it partially, the significance value of this product price variables is 0.827 , greater than the value of $\alpha(0.05)$. This indicates that this variable is not partially correlated with the dependent variables. However, since this study is focused on identifying the correlation between variables, thus in the regression equation above, this variable are remained included in order to build a comprehensive model. However, for further similar case studies, especially if the study focus on forecasting the future condition, it would be better to consider not using the product price variable in the regression.

To measure the level of validity of the above regression results, the results were tested using the value of $R$ Square, as shown in Table 4. The results of the validation test showed that the value of R-square was 0.670 , which means that about $67 \%$ changes or variances of the dependent variable (SMEs profit) can be explained by independent variables (ratio of production, product price ratio, and transportation cost ratio), while the remaining 33\% must be explained by variables outside the model.

Table 4 Validation Test

\begin{tabular}{|c|c|c|c|c|c|}
\hline & & & & Std. Error & Change Statistics \\
\hline Model & $\mathrm{R}$ & $\begin{array}{c}\mathrm{R} \\
\text { Square }\end{array}$ & $\begin{array}{l}\text { Adjusted } \\
\text { R Square }\end{array}$ & $\begin{array}{c}\text { of the } \\
\text { Estimate }\end{array}$ & R Square Change \\
\hline 1 &, $819^{\mathrm{a}}$ &, 670 & ,666 & , 14172 &, 670 \\
\hline
\end{tabular}

To identify the significance of the entire model, an F test was carried out in ANOVA. Based on the results of the F test, the statistical F statistic was 168.756 . Meanwhile the value of the $F$ table with a standard value of $\alpha=5 \%$ was 2.6. Comparing the value of the $\mathrm{F}$ statistic and the $\mathrm{F}$ table, it appears that the $\mathrm{F}$ statistic value was greater than the $F$ table value. This indicates that the model produced is significant, where the influence of the independent variables on the dependent variable tends to be more dominant than the effect of errors on the dependent variable.

\section{Conclusion and Recommendation}

Based on the results of the analysis described above, it can be concluded that the construction of the Soroja Toll Road had a different correlation on the productivity of small and medium-sized industries. For medium-sized industries, the presence of the Soroja Toll Road tended to have a positive correlation with their increased profit, production quantity, and price of goods. This is because the competitiveness of the medium-sized industry is better compared to that of small industries. With the presence of the Soroja Toll Road, the medium-sized industries were better able to capture a higher market share than the small-sized industries so that the presence of the Soroja Toll Road had a positive correlation with their increased number of produced goods and the profits among the medium-sized industries. For the small-sized industries, the presence of the Soroja Toll Road tended to have a positive correlation only with the price of their goods. As for the correlation between the presence of the Soroja Toll Road with the transport costs of SMEs, it appears that more than about $80 \%$ of both small and medium-sized industries were almost the same between after and before the construction of the Soroja Toll Road.

According to the linear regression results, based on three independent variables that were used as predictor variables for SME profits, the most dominant to the least dominant variables were: production quantity, transportation costs, and price of goods. To optimize the productivity of SMEs around the Soroja Toll Road corridor, the construction of the Soroja Toll Road alone was not enough to improve the local economy in the SME sector. The existence of the Soroja Toll Road needs to be supplemented by a strategy to optimize SME access to raw materials, access to capital and access to market expansion.

\section{Acknowledgment}

The authors wish to express their gratitude to ITB for providing funding for this research. The authors also would like to thank the local government of Bandung Regency for providing data and information. Finally, the authors would also like to thank all the respondents involved in this research.

\section{References}

[1] J. Q. Liu, and J. H. He, "An Empirical Study on the Development of Transportation Industry and National Economy," Journal of Transportation System Engineering, vol. 2, pp. 82-86, 2002.

[2] G. W. Skinner, "Marketing and social structure in rural China, Part I," Journal of Asian Studies, vol. 24, pp. 3-43, 1964.

[3] J. Howe, and P. Richards. Rural Roads and Poverty Alleviation. London: International Labour Organization, 2009.

[4] G. Porter, "The impact of road construction on women's trade in rural Nigeria," Journal of Transport Geography, vol. 3, no. 1, pp. 3-14, March, 1995.

[5] O. Z. Tamin. Perencanaan dan Pemodelan Transportasi. Bandung: Penerbit ITB, 2000. 
[6] Kusbiantoro. Memanusiakan Perencanaan Sistem Transportasi. 2nd ed. Bandung: Pusat Penelitian Pengelolaan Lingkungan, Wilayah dan Infrastruktur ITB, 2009.

[7] J. Sun, et al, "Study on the Relationship between Land Transport and Economic Growth in Xinjiang," Sustainability, vol. 10, no. 1, p. 135, 2018.

[8] H. Chung, "Some socio-economic impacts of toll roads in rural China," Journal of Transport Geography, vol. 10, pp. $145-156,2002$.

[9] J. D. Ortuzar, and L. G. Willumsen. Modelling Transport. 4th ed. West Sussex: Wiley, 2011.

[10] L. Bertolini, "Integrating Mobility and Urban Development Agendas: a Manifesto. disP - The Planning Review, vol. 48, no. 1, pp. 16-26, February, 2012.

[11] T. Firman, "The Continuity and Change in MegaUrbanization in Indonesia: A Survey of Jakarta-Bandung Region (JBR) Development," Habitat International, vol. 33, pp. 327-339, 2009.

[12] Pradono, and H. Pradhitasari, "Manfaat Invstasi Pembangunan Jalan Tol Bandung Intra Urban Dari Peerpektif Makro," Jurnal Tata Loka, vol. 13, no. 2, May, 2011.

[13] L. Prapti, et al., "Analisis Dampak Pembangunan Infrastruktur Jalan Terhadap Pertumbuhan Usaha Ekonomi Rakyat di Kota Semarang," Jurnal Dinamika Sosbud, vol. 17, no. 2, pp. 82-103, June, 2015.

[14] R. Anas, et al., "Kajian Kontribusi Investasi Infrastruktur Jalan Terhadap Perekonomian Wilayah Ditinjau Dari Sektor Transportasi Barang," in Proceedings of The 17th FSTPT International Symposium, August, 2014.

[15] B. Flyvbjerg, N. Bruzelius, and W. Rothengatter. Megaprojects and Risk: An Anatomy of Ambition. Cambridge: Cambridge University Press, 2003.

[16] S. Lenferink, et al, "Towards Sustainable Infrastructure Development Through Integrated Contracts: Experiences with Inclusiveness in Dutch Infrastructure Projects," International Journal of Project Management, vol. 31, no. 4, pp. 615-627, May, 2013.

[17] P. Rietvield, and R. Stough, "Institutions, Regulations and Sustainable Transport: A Cross-National Perpective," Transport Reviews, vol. 24, no. 6, pp. 707-719, 2004.

[18] D. Banister, "The Sustainable Mobility Paradigm," Transport Policy, vol. 15, pp. 73-80, 2008.

[19] P. McCann. Modern Urban and Regional Economics. Oxford: Oxford University Press, 2013.

[20] R. Adisasmita. Dasar- Dasar Ekonomi Wilayah. Yogyakarta: Graha Ilmu. 2010

[21] H. Li, et al., "Characterizing the Relationship between Road Infrastructure and Local Economy Using Structural Equation Modelling," Transport Policy, vol. 61, pp. 17-25, 2018 .
[22] S. E. Polzin, "Transportation/Land-Use Relationship: Public Transit's Impact on Land Use," Journal of Urban Planning and Development, vol. 125, no. 4, pp. 135-151, 1999.

[23] S. Won, S. E. Cho, and S. Kim, "The Neighborhood Effects of New Road Infrastructure: Transformation of Urban Settlements and Resident's Socioeconomic Characteristics in Danang, Vietnam," Habitat International, vol. 50, pp. 169-179, December, 2015.

[24] S. Bougheas, P. O. Demetriades, P. Theofanis, and T. P. Mamuneas, "Infrastructure, Specialization, and Economic Growth," Canadian Journal of Economics, vol. 33, no. 2, pp. 506-522, January, 2000.

[25] C. Shirely, and C. Winston, "Firm Inventory Behavior and The Returns From High-Way Infrastructure Investments," Journal of Urban Economics, vol. 55, pp. 398-315, 2004.

[26] J. P. Rodrigue, et al. The Geography of Transport Systems. Oxon: Routledge, 2006.

[27] J. Odeck, and M. Welde, "The Accuracy of Toll Road Traffic Forecasts: An Econometric Evaluation," Transportation Research Part A, vol. 101, pp. 73-85, 2017.

[28] A. Holl, "Highways and Productivity in Manufacturing Firms," Journal of Urban Economics, vol. 93, pp. 131-151, 2016.

[29] S. Sukirno. Mikro Ekonomi Teori Pengantar. Jakarta: PT Raja Grafino Persada, 2005.

[30] C. A. O'Flaherty. Transport Planning and Traffic Engineering. London: Arnold, 1997.

[31] N. G. Mankiw. Principles of Microeconomics. Orlando: The Dryden Press, 1997.

[32] World Bank. 2020. Small and Medium Enterprises (SMEs) Finance: Improving SMEs' access to finance and finding innovative solutions to unlock sources of capital [Online]. Available: https://www.worldbank.org/en/topic/smefinance [Accessed: 15-May-2020].

[33] Bank Indonesia, and LPPI. 2015. Profil Bisnis Usaha Mikro, Kecil dan Menengah (UMKM) [Online]. Available: https://www.bi.go.id/id/umkm/penelitian/nasional/kajian/D ocuments/Profil\%20Bisnis\%20UMKM.pdf.

[34] K. Kushnir. 2010. Methodology Note on the MSME Country Indicators (MSME-CI). World Bank IFC [Online]. Available: http://www.ifc.org.

[35] K. Kushnir, et al. 2010. Micro, Small, and Medium Enterprises Around the World: How Many are There, and What Affects the Count? World Bank IFC [Online]. Available: http://www.ifc.org.

[36] Central Bureau of Statistics of Indonesia. 2020. Definition of Micro, Small, and Medium Enterprises [Online]. Available: https://www.bps.go.id/subject/170/industrimikro-dan-kecil.html.

[37] Indonesia Law No. 20 of 2008 concerning Micro, Small and Medium Enterprises. 